\title{
CLADONIA CENOTEA (ACH.) SCHAER. ALSO FOUND IN SOUTHEAST GREENLAND*
}

\author{
F. J. A. DANIËLS and H. J.SIPMAN \\ Instituut voor Systematische Plantkunde, Utrecht
}

\section{SUMMARY}

Cladonia cenotea (Ach.) Schaer. is reported from Southeast Greenland. Its distribution in Greenland is mapped. A note is made on its ecology and distribution.

Cladonia cenotea (Ach.) Schaer. is a predominantly boreal lichen species with an alpine and northern distribution in Europe, North America and Asia. It also occurs in Australia (THOMSON 1967). In Greenland, which is mainly arctic, it is rare. It is known from a few scattered, more or less coastal stations (see map). These stations are:

1. Disko, ca. $70^{\circ}$ lat. N. (LYNGE 1937)

2. Kangersnueq, $68^{\circ} 50^{\prime}$ lat.N., $50^{\circ} 43^{\prime}$ long.W. (HANSEN 1962)

3. Nuerssorfiarqap avantunga, $67^{\circ} 46^{\prime}$ lat.N., $51^{\circ} 37^{\prime}$ long.W. (HANSEN 1962)

4. Ameralik, ca. $64^{\circ}$ lat.N., $50^{\prime}$ long.W. (DAHL 1950)

5. Agdluitsoq, Qordlortorssuaq, $60^{\circ} 45^{\prime}$ lat.N., $45^{\circ} 10^{\prime}$ long.W. (DAHL 1950). All these stations are along the west coast.

6. Gasøya and Husbukta (Vegasundet), Northeast Greenland, ca. $72^{\circ} 50^{\prime}$ lat.N. (LYNGE \& SCHOLANDER 1932)

Although quite a number of lichen collections from southern areas along the east coast has been made (see a.o. DaniëLs 1968 (survey), DaniëLS \& FerWERDA 1972, also GrøNLANDS BotanISKe UNDERSøgelse 1970, 1971) Cladonia cenotea was not met with until now.

However, in 1969 a few specimens of this species were found in the inner part of the Angmagssalik District, Southeast Greenland (Daniëls no 69D1500, 24.7. 1969, U., C). The species was growing at $500 \mathrm{~m}$ on the northern slope of the Cassiopefjeld, facing the valley Ilivnera: ca. $66^{\circ} 09^{\prime}$ lat.N., $37^{\circ} 21^{\prime}$ long.W. (map, 7 ).

It occurred in association with Cladonia crispata and C. gonecha in an Empetrum hermaphroditum - Vaccinium uliginosum ssp. microphyllum heath, rich in mosses, on the lower end of a ledge.

It was growing over a tight mat of mosses and liverworts.

In connection with its ecology and distribution we might put a few remarks. In its most southern (subarctic) station in Greenland (5), where birch forest is * Mededelingen van het Botanisch Museum en Herbarium van de Rijksuniversiteit te Utrecht No. 429. 
Distribution of Cladonia cenotea in Greenland.

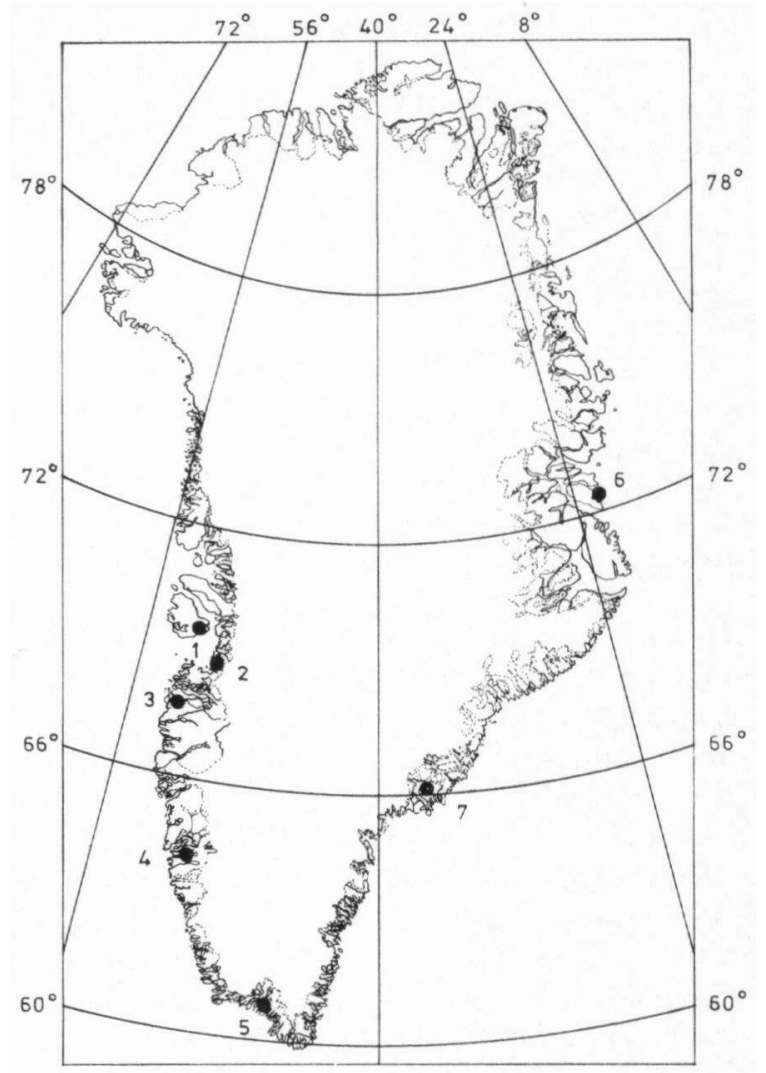

found, the species is very abundant on old trunks (DAHL 1950). Only in this station it is locally common. In the northern localities it is very scarce. Also in more southern regions (Europe) this trunk habitat is quite typical for this species, where it is considered as faithful species of the Cladonietum cenoteae Frey 1927. According to KLEMENT (1955) this community occurs: "Auf Baumstümpfen aller Art von der Niederung bis in die subalpine Region, fragmentarisch auch auf Rohhumusflächen an der Basis von Fichten und Kiefern, bei Bevorzugung trockenfauler, stark zersetzter Unterlagen".

In the northern (arctic) stations in Greenland, where trees and old trunks are lacking, the species occurs on light open, sheltered and humic (peaty) substrates (on and among mosses and liverworts). In ecological sense this habitat is rather comparable with the old trunk habitat.

Regarding its distribution in Greenland we conclude that Cladonia cenotea more often has been found along the west coast than along the east coast. However it does not seem that this can be explained by the fact that the west coast has been explored more often.

All east coast specimens show a somewhat reduced vitality. "All plants have 
destroyed and deformed podetia" (LYNGE \& SCHOLANDER 1932). The Angmagssalik specimens have rather short $(1 \mathrm{~cm})$ and stunted podetia.

We might suggest that ecological factors are involved. Possibly this boreal species has some benefit of the somewhat milder climate (due to the warm gulfstream) in the coastal areas of the west coast in comparison with that of the east coast localities, which are also influenced by the cold East Greenland Current.

To conclude Cladonia cenotea must be regarded now as a somewhat southern, somewhat oceanic (no records from distinct continental areas) species in Greenland (SSN, COO distribution type, HANSEN 1971).

\section{REFERENCES}

DAHL, E. (1950): Studies in the Macrolichen Flora of South West Greenland. Meddr. om Gronland 150: 2.

DANIËLs, F. J. A. (1968): Lichens collected during a Dutch botanical East Greenland expedition to the Angmagssalik area in 1966. Acta Bot. Neerl. 17: 345-348.

- \& H. F. FER WERDA (1972): Three interesting lichen finds from Southeast Greenland. Acta Bot. Neerl. 21: 166-168.

Grønlands Botaniske Undersøgelse 1970 and 1971. Stencils Botanisk Museum, Copenhagen.

HANSEN, K. (1962): Macrolichens from Central West Greenland. Meddr. om Gronland 163: 3.

- (1971): Lichens in South Greenland. Meddr. om Gronland 178: 6.

KLeMENT, O. (1955): Prodromus der mitteleuropäischen Flechtengesellschaften. Feddes Rep. Beih. 135: 5-194.

LYNGE, B. (1937): Lichens from West Greenland collected chiefly by Th. M. Fries. Meddr. om Grenland 118: 8.

LYNGE, B. \& P. F. ScholANDER (1932): Lichens from Northeast Greenland. Skr.om Svalbard og Ishavet 41.

Thomson, J. W. (1967): The lichen genus Cladonia in North America. University of Toronto Press. 